\title{
CLEC-2/Podoplanin による血小板の癌進展機構
}

\author{
白井俊光* \\ Platelet CLEC-2 promotes hematogenous metastasis and thromboinflammation in \\ tumor-bearing mice
}

Toshiaki SHIRAI

Key words: Platelets, Cancer, CLEC-2

\section{1. はじめに}

血小板は止血に必須である一方で, 古くからがん の進展を増悪することが知られている ${ }^{1)}$ 。血小板か ら放出された種々の生理活性物質が癌細胞の生存・ 遊走・血管新生・上皮間葉転換を促進し, 血中循環 癌細胞との凝集反応は免疫応答やシェアストレスか ら癌細胞を保護するとともに血管内皮への接着を促 進する。

我々は血小板活性化受容体 C-type lectin-like receptor 2 (CLEC-2) およびその生体内リガンドとし て Podoplanin（PDPN）を同定し, CLEC-2/PDPNの 相互作用が血栓止血を超えた様々な生理学的役割を 持つことを明らかにしてきた ${ }^{2)}$. 血栓形成において は, CLEC-2 は動脈血栓症および静脈血栓症を増悪 する一方で CLEC-2 欠損マウスは出血時間を延長し ないため, 出血リスクの少ない新規抗血小板薬の標 的分子として期待される.

興味深いことに, PDPN はリンパ管内皮などの正 常細胞に加えてメラノーマ, 扁平上皮癌, グリオー マなどいくつかの癌細胞上に高発現する。したがっ て, 血小板 CLEC-2 は癌細胞 PDPN との相互作用に より癌進展を増悪していると考えられる。しかしな がら, 遺伝的 CLEC-2 欠損マウスは出生直後致死,

*責任者連絡先：

山梨大学医学部臨床検査医学講座

干 409-3898 山梨県中央市下河東 1110

Tel: 055-273-9884

E-mail: tshirai@yamanashi.ac.jp
血管リンパ管吻合, 血小板減少など様々な表現型を 示すことから，これらの影響を排除した動物モデル の作成・解析が必要である. そのため, 今日まで血 小板 CLEC-2 の癌進展における役割は明らかになっ ていない.

本研究において, 我々は抗体により巨核球・血小 板 CLEC-2 が欠損する現象に着目し ${ }^{3)}$ ，ラット抗マ ウス CLEC-2 モノクローナル抗体 2A2B10 樹立し た. 抗体投与後の表現型を解析した後, PDPN 発現 マウスメラノーマB16F10を用いて, 癌進展におけ る血小板 CLEC-2 の病態生理学役割を調査した ${ }^{4)}$.

\section{2. 抗 CLEC-2 抗体 2A2B10 による血小板特異的 CLEC-2 欠損マウスの作成}

GPVI と同様に, 抗 CLEC-2 抗体は一時的な血小板 減少を生じた後, CLEC-2 欠損血小板が産生され る $^{3)}$. 我々はラット抗マウス CLEC-2 モノクローナ ル抗体 $2 \mathrm{~A} 2 \mathrm{~B} 10$ を樹立し, 腹腔内投与後の表現型を 解析した。他グループの報告と同様に2A2B10の単 回投与は一過性の血小板減少を認め, 血小板上の CLEC-2 欠損状態を 8 日間維持した（図 $1 \mathrm{~A}, \mathrm{~B}$ ). $2 \mathrm{~A} 2 \mathrm{~B} 10$ を 7 日毎に反復投与すると 2 回目以降は血 小板減少を惹起せず (図 $1 \mathrm{~A}$ ), 34 日後まで血小板 CLEC-2 欠損状態を維持した (図 1B)。この際, 貧 血, 血小板減少, および血管・リンパ管吻合は認め られなかった。

マウスでは白血球上にも CLEC-2 が発現するため, 2A2B10 投与後の白血球上の CLEC-2 の発現量の変 
A

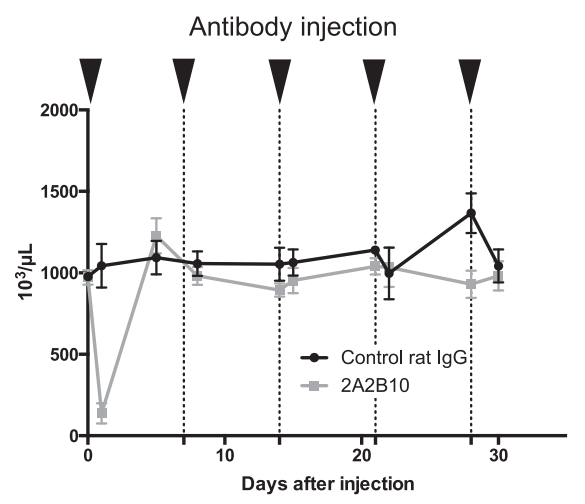

C

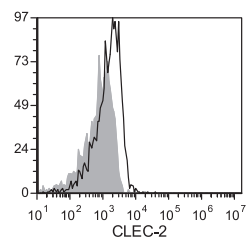

Control rat IgG

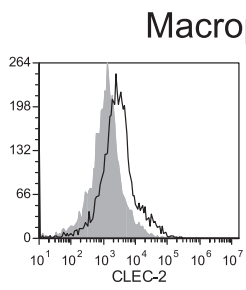

Control rat IgG
B

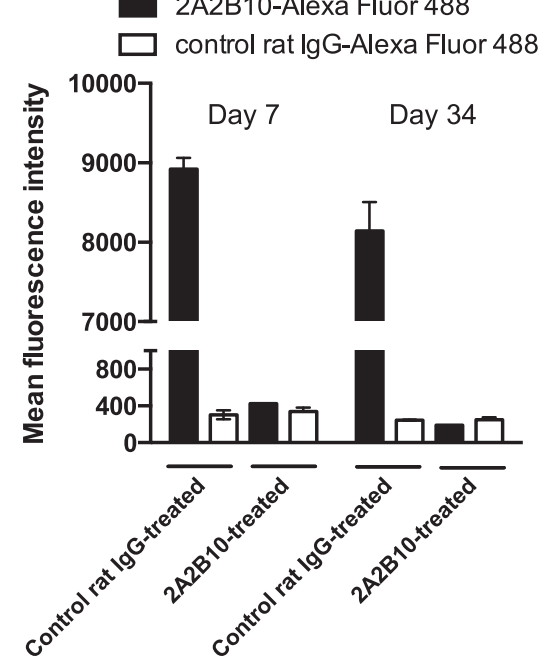

B cells

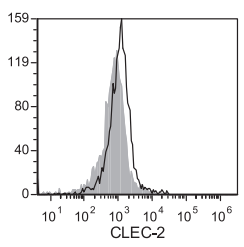

Control rat $\lg G$

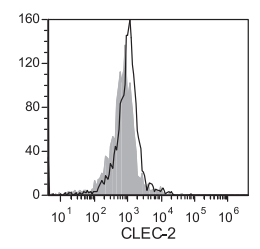

2A2B10

Peripheral neutrophils
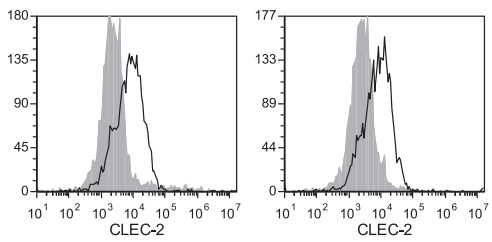

Control rat IgG

2A2B10

$\mathrm{D}$

Peripheral neutrophils

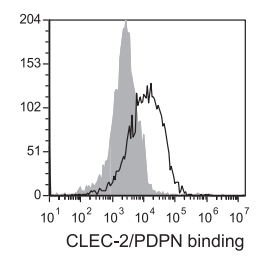

Control rat IgG

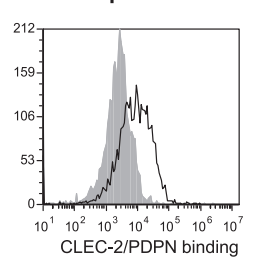

2A2B10

図 1 抗 CLEC-2 抗体 2A2B10 による血小板特異的 CLEC-2 KO マウスの作成

（A）野生型 C57BL/6 マウスに Control rat IgG あるいは 2A2B10（8 mg/kg, i.p.）を投与した時の血小板数の変動.（B） Flow cytometry 法による血小板 CLEC-2 発現量の定量. (C) 2A2B10 投与後の白血球上の CLEC-2 発現量. (D) 2A2B10の中和活 性の解析. Control rat IgG あるいは 2A2B10 と共培養された好中球に対するリコンビナント PDPN 結合量を Flow cytometry 法で測定した. 
化を Flow cytometry 法で解析した。 NK 細胞, B 細 胞, マクロファージ, 好中球すべての細胞において, 2A2B10 投与による CLEC-2 発現量の低下は認めら れなかった（図 1C).さらに，好中球 CLEC-2に 2A2B10を結合させた後にリコンビナントマウス PDPN が結合するか Flow cytometry 法で解析した所, 2A2B10は CLEC-2/PDPN 結合量を抑制しなかった (図1D)。したがって2A2B10に中和活性は無い事が 明らかになった。

以上の結果より, 2A2B10 は遺伝的 CLEC-2 欠損マ ウスに認められる表現型を示すこと無く, 後天的に 血小板 CLEC-2 を特異的に欠損させた.

\section{CLEC-2 は血行性転移を促進する}

本研究ではPDPNを発現するマウスメラノーマ細 胞B16F10を用いる事にした。まず我々は血行性転 移に対するCLEC-2の機能を明らかにするため, GFP をトランスフェクションしたB16F10（B16F10-GFP） を尾静脈より注射し実験的肺転移モデルを作成した (図 2A). 移植時の血小板数は血行性転移に決定的な 影響を与えるため, 2A2B10 抗体投与 4 日後の時点で 細胞を注射した。癌細胞移植 14 日後, 肺 GFP 蛍光 強度を IVIS により測定した所, 2A2B10 群は Control rat IgG 群に比べて有意に GFP 蛍光強度を減弱した (困 2B). 肺の重量も同様に2A2B10投与群で有意に 低下していた（図 2C).B16F10-GFP を右側腹部に皮 下移植し, 21 日後の耳静脈の血流を観察し血中循環 癌細胞数を測定したところ, 実験的肺転移モデルと 一致して 2A2B10 群では有意に血中循環癌細胞が 減少していた（図 2D）。従って, 血小板 CLEC-2 はB16F10の血行性転移を促進することが明らかに なった。

\section{CLEC-2 は in vivoにおける腫瘍増殖を抑制し ない}

次に我々は腫瘍増殖について調査した。まずin vitro において B16F10 とマウス洗浄血小板を共培養 し，48 時間後の細胞数を測定した. 野生型マウスあ るいは Control rat IgG 投与マウス由来の洗浄血小板
の添加により, 血小板濃度依存的に B16F10 細胞数 が増加した (図 3A, B). 一方, 遺伝的 CLEC-2 欠損 マウスあるいは $2 \mathrm{~A} 2 \mathrm{~B} 10$ 投与マウス由来の洗浄血小 板では細胞増殖促進効果が消失した. 次に, 血小板 活性化上清（図 3C）あるいはリコンビナント mCLEC-2-rFc（図 3D）をB16F10 に添加すると，血 小板活性化上清は細胞増殖を促進したが, mCLEC-2$\mathrm{rFc}$ では変化がなかった，すなわち，B16F10による CLEC-2 依存的な血小板活性化が増殖因子など種々 の生理活性物質の放出を誘導することによって細胞 増殖が促進されることが明らかになった。

そこで我々は，マウスの右腹側部にB16F10を皮 下移植して経時的に腫瘍体積を測定した（図3E）。 その結果, in vivoでは 2A2B10 群は腫瘍増殖を抑制 しなかった（図 $3 \mathrm{~F}$ ).

\section{CLEC-2 は腫瘍内血栓形成を増悪する}

$2 \mathrm{~A} 2 \mathrm{~B} 10$ 投与マウスが腫瘍増殖を抑制しない原因 を探索するため, 我々は移植 21 日後の腫瘍の免疫組 織学的解析を行った．腫瘍血管 (CD34) および血小 板（CD41）とフィブリノゲンの沈着を観察した所 (図 4A)，2A2B10 投与群では腫瘍血管密度には変化 は認められなかった（図4B）。

しかしながら，2A2B10群では腫瘍内にフィブリ ノゲンが沈着している血管の割合が有意に低下して いた（図 4A，C）。腫瘍ライセートを用いたウエス タンブロッティング法では, 腫瘍内に沈着した血小 板が 2A2B10 群で有意に減少していた（図4D). 次 に, 腫瘍摘出前に FITC 標識デキストランを投与し, 血液循環が維持されている機能性血管の割合を解析 した。血栓形成とは反対に, $2 \mathrm{~A} 2 \mathrm{~B} 10$ 群は機能性血 管の割合が Control rat IgG 群に比べて有意に増加し ていた（四 4E).

以上の結果から, 2A2B10 投与マウスが腫瘍増殖 を抑制できなかった理由として，血小板 CLEC-2 欠 損により腫瘍内の血栓形成が抑制されて機能性血管 が増加することにより, 腫瘍への栄養・酸素の供給 が改善した可能性が示唆された. 
A

$\nabla$ Antibody administration

$\nabla$ B16F10 inoculation

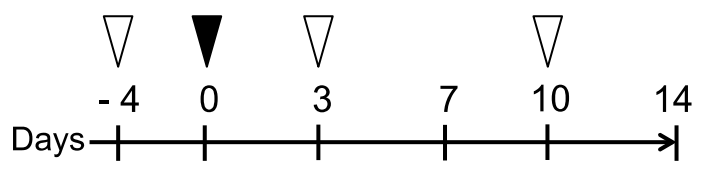

B
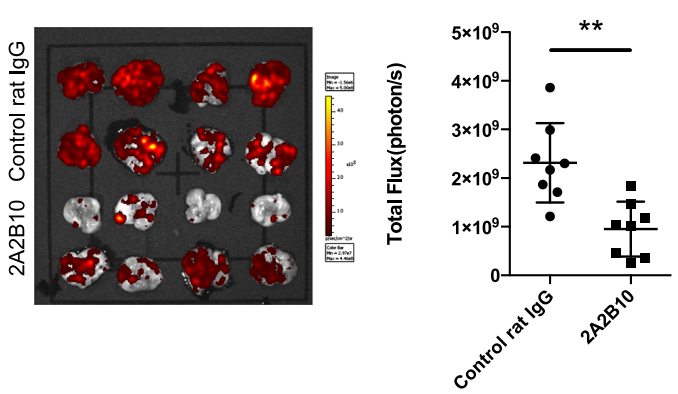

C

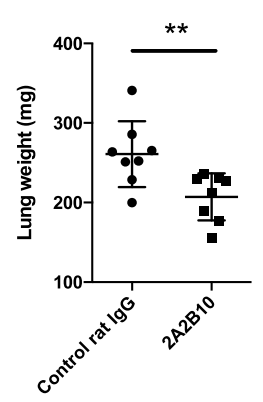

D
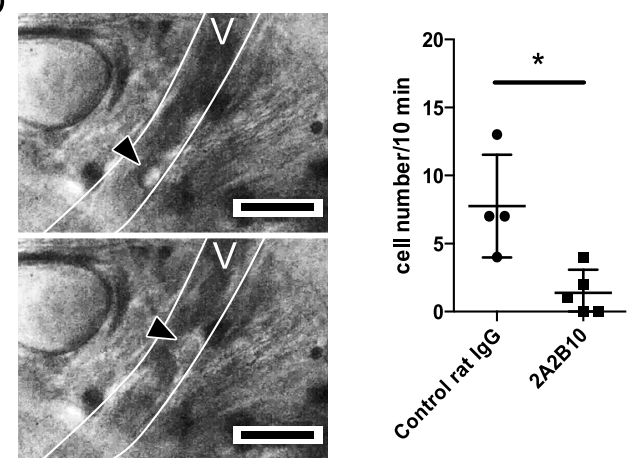

図 2 CLEC-2 除去は血行性転移を抑制する

（A）実験的肺転移モデルの概要．移植 14 日後の肺における B16F10-GFPの蛍光強度を IVISにより測定し（B), 同時に肺 の重量を測定した (C)。**P<0.01（Student’s t-test）（D）B16F10-GFPを皮下移植した 21 日後，耳静脈の血流を蛍光顕微 鏡下で撮影し， 10 分間 GFP 陽性細胞数をカウントした. Scale bar $=50 \mu \mathrm{m} . * \mathrm{P}<0.05$ (Student's t-test).

\section{CLEC-2 は Thromboinflammation の増悪によ} り予後を不良にする

2A2B10 投与マウスは実験的肺転移および腫瘍内 の血栓形成を抑制したが，腫瘍増殖は抑制しなかっ た.これらの影響が予後改善に寄与するか皮下移植 後に生存解析を行った。興味深いことに, CLEC-2 欠損状態を維持できる 30 日間において，2A2B10 群 は Control rat IgG 群に比べて生存率が有意に増加し た（四 5A).
癌患者において, 転移を伴う癌進展に続く2 番目 の死因は癌関連血栓症である ${ }^{5)}$. 2A2B10 投与マウス が腫瘍内の血栓形成を抑制していた事から, 我々は CLEC-2 が全身性に血栓形成を増悪している可能性 に着目した. 腫瘍移植 21 日後, 肺の血栓形成を免疫 組織学的に解析すると, 2A2B10 群は Control rat IgG 群と比較してフィブリノゲンの沈着が有意に減少し ていた（図 5B)。さらに, 2A2B10 群は炎症性サイト カイン IL-1 $\beta$, IL-6 の血中濃度が低下し（図 5C), 大 腿四頭筋重量の減少（図 5D）および貧血（図 5E） 
A

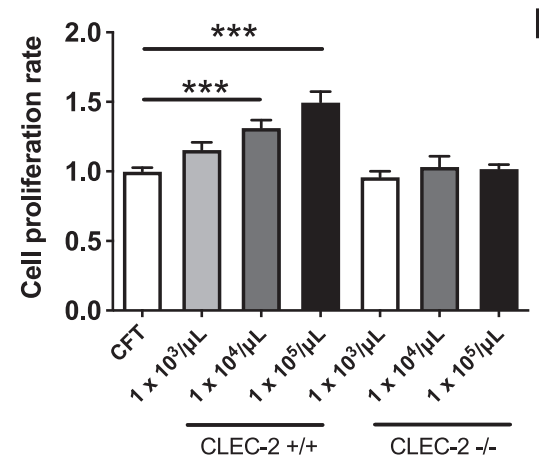

B

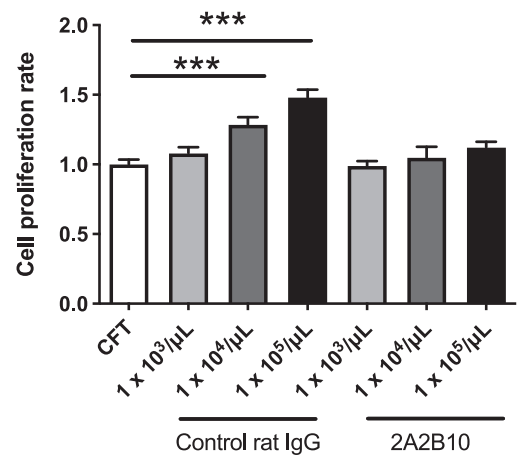

C

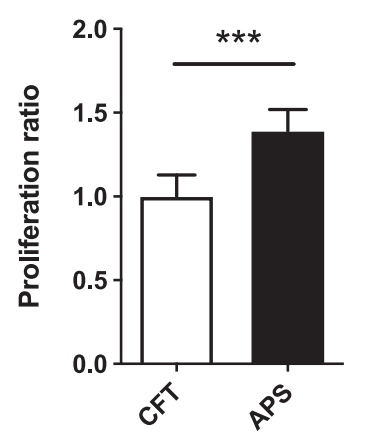

D

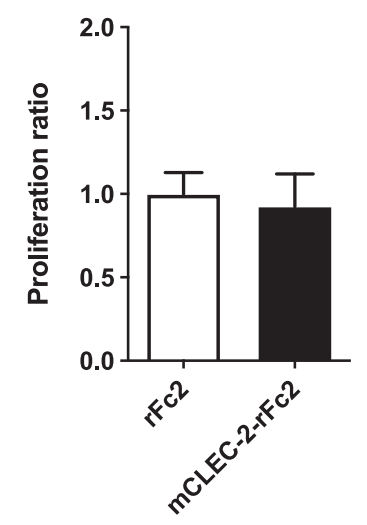

E

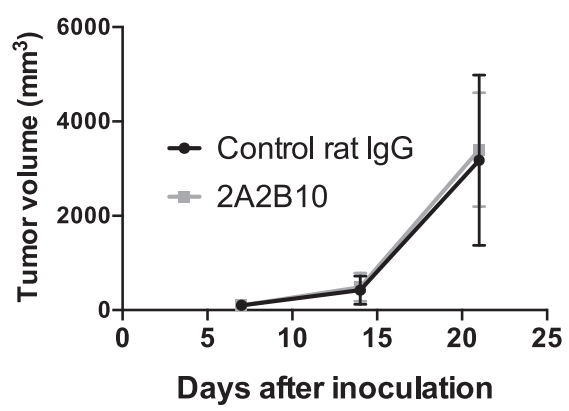

図 3 CLEC-2 除去はin vivoにおける腫瘍増殖を抑制しない

（A-D）In vitroに抢ける B16F10 の細胞増殖. B16F10 と遺伝的 CLEC-2 KO マウス（A）あるいは 2A2B10 抗体投与マウス （B）の洗浄血小板を添加し，48 時間後の細胞数をカウントした。（C）血小板活性化上清（APS）による細胞増殖促進効 果.（D）リコンビナント mCLEC-2-rFc2 添加による細胞増殖促進効果. ***P $<0.001$, (Dunnett's t-test). (E) 皮下移植後の $\mathrm{B} 16 \mathrm{~F} 10$ 腫瘍体積の経時的解析.

の程度が Control rat IgG 群と比較して有意に軽微 だった．以上の結果から，CLEC-2/PDPN 相互作用に よる血栓形成が慢性炎症を増悪し, 癌関連血栓症お よび癌悪液質を増悪する可能性が示唆された。

\section{7. おわりに}

癌細胞において PDPN は遊走, 浸潤, 転移を促進 する分子として注目されてきた。一方 CLEC-2 は適 切な実験モデルが構築されておらず，その役割は不 明であった。本研究は CLEC-2 を標的とした癌研究 
A Control rat lgG

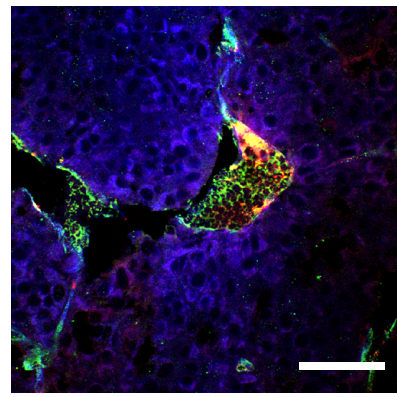

CD34

Fibrin(ogen)

CD41
B
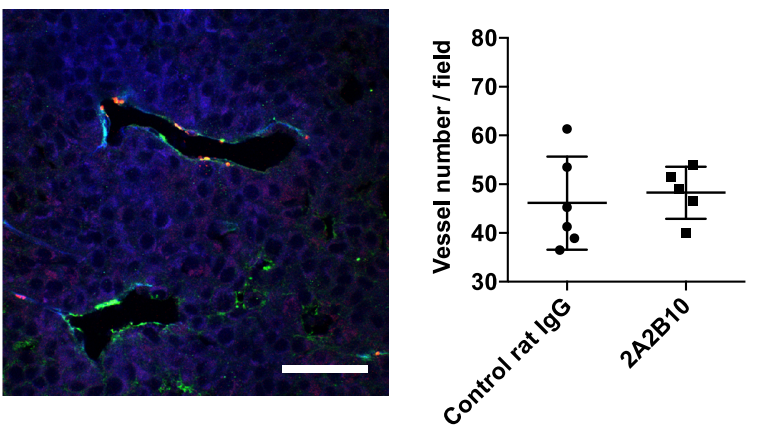

C
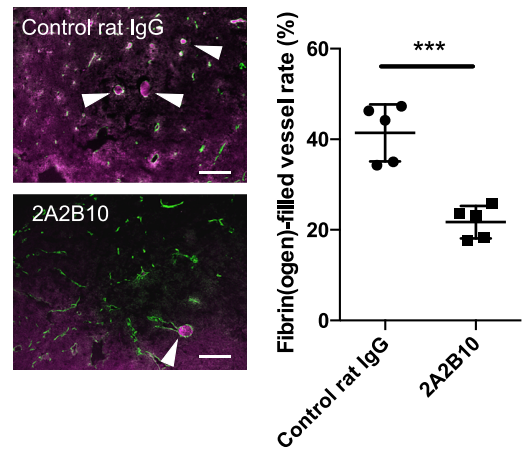

D
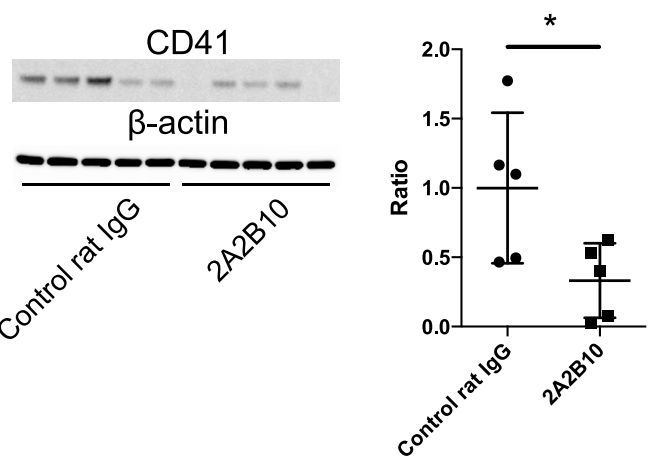

E
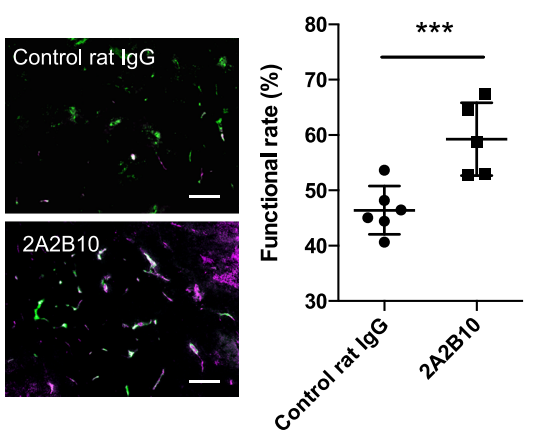

図 4 CLEC-2 除去は腫瘍内の血栓形成を抑制し血液循環を改善させる

(A) 移植 21 日後の腫瘍切片における血管 (青), フィブリノーゲン (緑), 血小板 (赤). Scale bar $=50 \mu \mathrm{m} . \quad(\mathrm{B})$ 腫瘍血 管密度の定量.（C）フィブリノーゲン（マゼンタ）の詰まった腫瘍血管（緑）の定量解析. *P $<0.05$ （Student’s t-test）. (D) 移植 21 日後の腫瘍ライセートにおける血小板 (CD41) の半定量. タンパク量を $\beta$-actin で補正した. *P $<0.05 （$ Student' s t-test).（E）腫瘍内の機能性血管の割合. FITC 標識デキストラン（緑）を灌流し，血液循環のある血管（緑+マゼンタ） の割合を解析した. $* * * \mathrm{P}<0.001$ (Student's t-test).

の初めての報告である.

グリオーマは癌関連血栓症を高頻度で引き起こす 癌種の 1 つである.グリオーマ患者の組織学的解析
から, PDPN 発現が腫瘍内血小板凝集塊に関与して 打り, PDPN 発現がVTE発症リスクを増強する事が 報告されている ${ }^{6)}$ 。さらに，マウスモデルに抏いて 
A

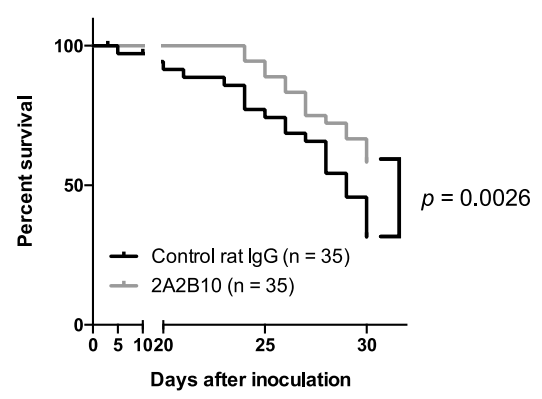

B

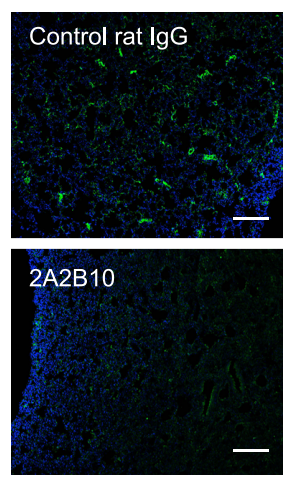

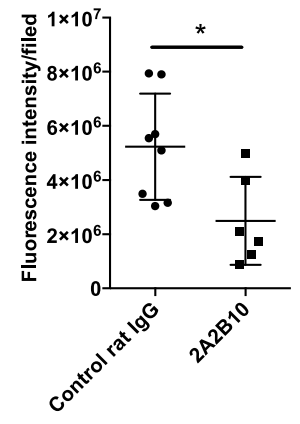

Nuclei

Fibrin(ogen)

C
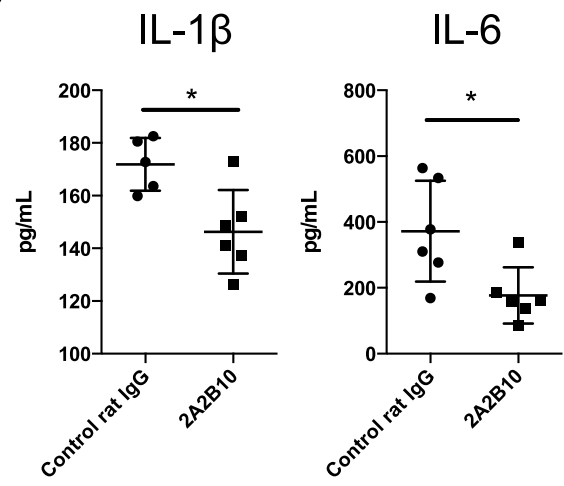

D

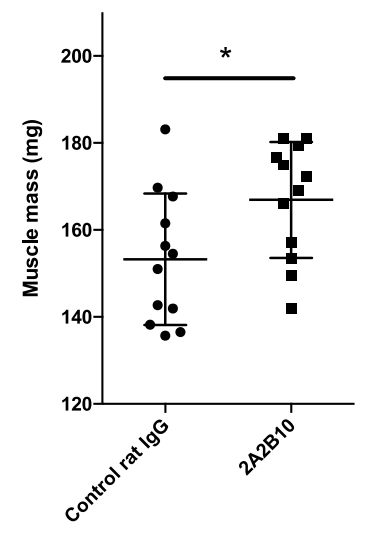

E

\begin{tabular}{ccccc}
\hline & $\begin{array}{c}\text { Intact } \\
(\mathbf{n = 6})\end{array}$ & $\begin{array}{c}\text { Control rat IgG } \\
(\mathbf{n = 6})\end{array}$ & $\begin{array}{c}\text { 2A2B10 } \\
(\mathbf{n = 7})\end{array}$ & P value \\
\hline $\mathrm{RBC}\left(10^{6} / \mu \mathrm{L}\right)$ & $9.82 \pm 0.93$ & $3.65 \pm 0.25$ & $5.70 \pm 0.64$ & $<0.05$ \\
HGB $(\mathrm{g} / \mathrm{dL})$ & $14.17 \pm 1.33$ & $5.50 \pm 0.34$ & $8.00 \pm 0.85$ & $<0.05$ \\
HCT $(\%)$ & $46.33 \pm 4.08$ & $19.00 \pm 0.34$ & $28.29 \pm 2.55$ & $<0.05$ \\
WBC $\left(10^{3} / \mu \mathrm{L}\right)$ & $14.62 \pm 3.34$ & $4.27 \pm 0.34$ & $4.03 \pm 0.35$ & N.S. \\
PLT $\left(10^{3} / \mu \mathrm{L}\right)$ & $966.7 \pm 149.4$ & $530.0 \pm 49.3$ & $481.4 \pm 29.6$ & N.S. \\
\hline
\end{tabular}

図 5 CLEC-2 除去は Thromboinflammation を抑制し, 予後を改善する

（A）皮下移植後の生存解析. P 值はログランク検定により算出した. (B-E）癌悪液質に関する解析. 腫瘍移植 21 日後にサ クリファイスし, 肺切片におけるフィブリノゲンの沈着 $(\mathrm{B})$, 血漿中 IL-1 $\beta$ および IL-6 濃度 $(\mathrm{C})$, 大腿四頭筋重量（D), 血液学的解析（E）を行った。 $* \mathrm{P}<0.05$ (Student's t-test)

グリオーマ細胞由来の PDPNが腫瘍内の血小板凝集 を増悪している事が報告された ${ }^{7)}$ 。これらは本研究 と一致する結果であり, CLEC-2を標的とした新規 抗血小板剤はグリオーマ患者の癌関連血栓症の予 防・治療として有益である可能性が高い. 同時に, 機能性血管の増加は腫瘍深部への抗がん剂の輸送の 観点からも有効かもしれない.
本研究で明らかにされていない点も多い, 癌関連 線維芽細胞 (Cancer-associated fibroblasts: CAFs) や 癌関連マクロファージ（Tumor-associated macrophages: TAMs）などの癌間質細胞にも PDPNが発現 することが知られているが, これらの PDPN 発現癌 間質細胞に対する血小板 CLEC-2 の機能は全くわ かっていない. 今後も精力的に研究を続け, 癌にお 
ける CLEC-2 の病態生理学的役割について明らかに していきたい.

\section{謝辞}

本研究を行うにあたり, ご協力頂いた著者の皆様, また実験をサポートしていただいた中澤久一郎様, 小松千覀紀様, 福田初菜様, 大竹志門先生に感謝い たします。 また, 本研究は最先端・次世代研究支援 プログラム（LS052）の助成を受けて行われました。 感謝いたします。

著者の利益相反 $(\mathrm{COI})$ の開示 :

本論文発表内容に関連して開示すべき企業等との利 益相反なし

\section{文献}

1) Haemmerle M, Stone RL, Menter DG, Afshar-Kharghan V, Sood AK: The platelet lifeline to cancer: Challenges and opportunities. Cancer Cell 33: 965-983, 2018.
2) Suzuki-Inoue K, Tsukiji N, Shirai T, Osada M, Inoue O, Ozaki Y: Platelet CLEC-2: Roles beyond hemostasis. Semin Thromb Hemost 44: 126-134, 2018.

3) May F, Hagedorn I, Pleines I, Bender M, Vogtle T, Eble J, Elvers M, Nieswandt B: CLEC-2 is an essential plateletactivating receptor in hemostasis and thrombosis. Blood 114: 3464-3472, 2009.

4) Shirai $T$, Inoue $O$, Tamura $S$, Tsukiji $N$, Sasaki T, Endo $H$, Satoh K, Osada M, Sato-Uchida H, Fujii H, Ozaki Y, SuzukiInoue $\mathrm{K}$ : C-type lectin-like receptor 2 promotes hematogenous tumor metastasis and prothrombotic state in tumorbearing mice. J Thromb Haemost 15: 513-525, 2017.

5) Khorana AA, Francis CW, Culakova E, Kuderer NM, Lyman GH: Thromboembolism is a leading cause of death in cancer patients receiving outpatient chemotherapy. J Thromb Haemost 5: 632-634, 2007.

6) Riedl J, Preusser M, Nazari PM, Posch F, Panzer S, Marosi C, Birner P, Thaler J, Brostjan C, Lotsch D, Berger W, Hainfellner JA, Pabinger I, Ay C: Podoplanin expression in primary brain tumors induces platelet aggregation and increases risk of venous thromboembolism. Blood 129: 18311839, 2017.

7) Costa B, Eisemann T, Strelau J, Spaan I, Korshunov A, Liu HK, Bugert P, Angel P, Peterziel H: Intratumoral platelet aggregate formation in a murine preclinical glioma model depends on podoplanin expression on tumor cells. Blood Adv 3: 1092-1102, 2019. 